\title{
Covid-19 and international cooperation: IR paradigms at odds
}

\author{
Rajesh Basrur $^{1,2} \cdot$ Frederick Kliem $^{1}$
}

Received: 8 May 2020 / Accepted: 21 September 2020 / Published online: 9 November 2020 (c) Springer Nature Switzerland AG 2020

\begin{abstract}
The Covid-19 pandemic is a global challenge calling for a global response. But the actual responses of states, while exhibiting considerable international cooperation, are predominantly competitive and self-centered. This raises important questions about the utility of our basic intellectual tools - in the form of International Relations Theory (IRT) - for understanding the pattern of these responses. IRT analyzes inter-state dynamics and explains the extent to which states and institutions do or do not cooperate. This critique focuses on theories that stress competition (realism), those that focus on cooperation (liberalism) and those emphasising ideational constructions that could go either way (constructivism and normative theory). It seeks to elucidate the relative strengths of these theories-what they can tell us and what they cannot - in understanding responses to the current pandemic. It concludes that, while all the identified approaches have something to offer, realist theory, which highlights the prioritization of national interests over collective action, provides the most optimal approach for a full understanding of global responses to Covid-19. The analysis helps draw lessons for policy responses to this and other global crises, such as climate change.
\end{abstract}

Keywords Covid-19 $\cdot$ International relations theory $\cdot$ Realism $\cdot$ Liberalism . Constructivism $\cdot$ Normative theory

Covid-19 has proven to be one of the greatest global challenges of this generation. A pandemic is not confined by national boundaries and Covid-19 has tested the international resolve to cooperate. The globalized, interconnected world, with its integrated supply-chains, constant trans-border flows of goods, services and money and seamless people-to-people connectivity, is exceptionally vulnerable to pandemics. In

Rajesh Basrur

israjesh@ntu.edu.sg

1 S. Rajaratnam School of International Studies, Nanyang Technological University, Singapore, Singapore

2 Oxford School of Global and Area Studies, University of Oxford, Oxford, UK 
this context of hyper-globalization, the rapid spread of Covid-19 from China, where it first emerged, to the rest of the world is symptomatic of our times. Logic would suggest that collective international action is both necessary and possible because it is in every state's own interest to tackle the pandemic effectively.

However, the reality looks rather different. Both great powers, China and the United States, have hitherto failed to provide the necessary global leadership and are instead embroiled in an increasingly heated great power competition (Rudd 2020). The World Health Organization (WHO) and the United Nations (UN) have played, at best, the role of supporting actors. Because international organizations can only be as effective as their members allow them to be, no blame can be assigned to either the UN or its health agency. The WHO as the only global public health organization of magnitude has remained relatively ineffective owing to the conflicting priorities of its members. And even the European Union (EU) and the Association of Southeast Asian Nations (ASEAN) have been constrained by outbreaks of nationalism and unilateral knee-jerk reactions. The two most integrated regional organizations could reasonably have been expected to assume a greater role in regional coordination of a transboundary mutual challenge.

This commentary seeks to evaluate the basic intellectual tools of the discipline of International Relations (IR) and their effectiveness in comprehending the crisis. To this end, it assesses the main paradigms of International Relations Theory (IRT) and their potential for grasping global and national policy responses to the crisis, in particular to understand the problem of why states fail to cooperate in the pursuit of common interests. IR scholars are often criticized for their alleged theoretical simplification of the complexity of inter-state relations and state behavior. IRT is, therefore, often dismissed-not entirely without justification-by those outside the field as a purely academic exercise. However, evaluation of IRT in the Covid-19 context has important practical implications. It allows appreciation of those intellectual tools that best (and least) explain current policy responses, helps shape expectations about the degree of international cooperation that can be expected in the future, and suggests optimal ways to craft appropriate and pragmatic policies to tackle them.

The analysis asks which theoretical paradigm within IRT is best placed to both interpret current and anticipate future responses to pandemics and other global security challenges. It examines three disciplinary paradigms or classes of explanation and what they illuminate, as well as what they do not, about the current situation: (a) the realist, (b) the liberal and (c) ideational approaches (constructivism and normative theory). It concludes that all the approaches have something to offer, but it is the realist approach that best mirrors reality and provides the most useful foundation on which to assess optimal policy responses to it.

\section{The realist approach}

In the realist view, the basic principles of international politics never change. International affairs always remain essentially a struggle for power among self-interested states. Since realism is not a unitary theory, different branches of realism rely on different independent variables. Classical realists like Hans Morgenthau see perpetual 
conflict rooted in an innately selfish human nature, which translates into competitive state behavior (Morgenthau 1985). Neorealists such as Kenneth Waltz focus on an inherently competitive international system without a central organizing authority that monopolizes power to manage inter-state relations and protect states from one another (Waltz 1979). Within this anarchic international system, states are the primary actors and employ self-help strategies to survive and, depending on the exact branch of neorealism, to maximize power or security. Because of an inevitably asymmetric distribution of power, the anarchic condition of international affairs may compel weaker states to either balance against or bandwagon with more powerful ones. Neoclassical realists marry neorealism's systemic assumptions with domestic level factors that either facilitate or circumscribe foreign policy, for instance domestic institutions, government-society relations, and leadership perception (Ripsman et al. 2016).

Realism is generally pessimistic about the prospects for cooperation and mutual support among states. It would immediately predict the national self-help and "us first" mentality that characterizes the global management of Covid-19 and its consequences. Travel and entry bans, international scapegoating, great power competition and pharmaceutical protectionism are ubiquitous.

Even in the world's most integrated supranational organization, the European Union (EU), member states readily violate otherwise sacrosanct principles of cooperation, and realists would not be surprised by how quickly lofty European ideals and norms made way for national self-help once the Covid-19 crisis hit the continent. The outbreak was followed by immediate violation of many existing EU regulations: competition law, fiscal discipline, and freedom of movement. As countries closed their borders, EU capitals went into full nationalist gear (Guardian 2020a). Without any EU-consultation process, a number of EU countries immediately closed their borders and decreed export bans. When Italy, one of the worst affected countries in the world, asked fellow EU members for emergency relief with critical medical supplies, for several weeks it was met with precisely what realism would expect: its neighbors violated the EU's single-market spirit by decreeing export bans on pharmaceutical equipment (Braw 2020; Reuters 2020).

Dismayed by the lack of European solidarity, Rome was happy to accept support from China, which, though itself badly affected, sent medical equipment and experts immediately. Far from being altruistic, however, Beijing aims to rewrite the Covid19 narrative. It does not want to be seen as the point-of-origin of the Covid-19 virus and views the pandemic as an opportunity to come out ahead of the United States in a zero-sum competition for global primacy. In Italy and elsewhere, China's "mask diplomacy" is a noteworthy public relations coup (Kliem and Chong 2020). Beijing wants to be recognized globally as a responsible provider of public health goods in the absence of US leadership, and thereby, progress towards its ultimate objective of comprehensive power accumulation relative to Washington.

Indeed, the US has not only been absent in terms of leadership, but has also actively engaged in nationalistic self-help at the expense of others. President Donald Trump of the United States, Europe's closest non-EU ally and partner, tried to lure CureVac, a German firm that was developing a promising Covid-19 vaccine technology, to relocate its Covid-19 research and development division to the US 
and to guarantee exclusive American access to the firm's products (Die Welt 2020). Similarly, Trump sought to block the sale of masks to Canada by a US-based firm (MacCharles and Ballingall 2020), though a compromise was arrived at later. The US (like other countries, e.g. Japan) has also sought to restructure global supply chains in order to bypass dependence on China (Pamuk and Shalal 2020), which-if it succeeds-will be a radical and long-term change.

Realists also point out that international institutions do not enable states to concentrate on greater long-term gains for everyone. Instead, international anarchy forces states to treat international organizations and institutions essentially like the international system itself: as an arena for zero-sum competition. Indeed, as realism predicts, the World Health Organization (WHO) has become highly politicized. For example, because of the PRC's refusal to accept Taiwan as a diplomatically independent, sovereign nation state, the WHO disregards Taiwan's experience with Covid-19 as well as related research and development results. Allegedly bowing to pressure from Beijing, the WHO does not recognize Taiwan and refuses to include Taipei's very successful pandemic management strategies in its reports on global research efforts (Financial Times 2020). This also supports the neoclassical realists' argument about domestic factors. It shows how domestic ideology shapes foreign policy decisions in China and hinders international cooperation.

If a severe transboundary global crisis cannot spur international cooperation, then what can? Realism reminds us that, because of the trust deficit systemically inherent in an international system characterized by anarchy, states hesitate to forgo their first instinct for self-help and zero-sum games, even amidst a common global challenge.

\section{The liberal approach}

Liberal theory highlights four imperatives for cooperation: interdependence, transnationalization, the growth of international institutions, and democracy (Doyle and Recchia 2011; Nye 1988).

When the fates of states are bound together, liberals claim, they must cooperate or pay a very high price. The global economy, for instance, is a complex network of trade, finance and manufacturing that places a premium on cooperation. From this perspective, states must cooperate to stem pandemics that flow seamlessly across the world and impose high costs on all societies. They must share knowledge and material resources to counter a scourge that harms them all. They certainly do so, for example, in US-led efforts to ensure the reliable availability of equipment to combat pandemics (Tribune 2020). But they do not cooperate consistently. The United States has sought to corner scarce medical supplies (Bradley 2020), European states have failed to coordinate policy (The Guardian 2020a), and China and the United States are squabbling over responsibility (Shi and Wu 2020). In short, the pattern is much as in another arena of contest between interdependent states: the as yet unfinished "trade war."

Why? Interdependence does not automatically produce cooperation. It is only when the breakdown of interdependence raises the prospect of serious catastrophe that states cooperate. When nuclear-armed states are on the verge of war, 
for instance, they engage in tacit cooperation by practicing extreme caution and often seek explicit accommodation through talks, as was the case in Cold War crises. Even so, they continue to compete through arms racing, alliance building and occasional brinkmanship. Comparatively low levels of interdependence amidst the Covid-19 outbreak are unlikely to generate high levels of cooperation as the threat to national survival is limited.

The onset of pandemics has certainly produced unprecedented cooperation among epistemic communities, such as virologists, in a transnationalized world. Scientists from many countries have worked together to manage the threat of a viral outbreak ever since the outbreak of Severe Acute Respiratory Syndrome (SARS) in 2002. The appearance of the Middle East Respiratory Syndrome (MERS) in 2012 quickly led to the activation of a scientific network that has been dubbed the "SARS club" (Butler 2012). More broadly, the onset of MERS spurred global research, producing as many as 883 scientific papers in 92 countries between 2012 and 2015 (Zyoud 2016). Likewise, as the New York Times has noted, the Covid-19 outbreak has galvanized unparalleled cooperative research in which scientists have bypassed standard protocols and competitive secrecy to engage in shared efforts (Apuzzo and Kirkpatrick 2020). But, not for the first time, politics has trumped cooperation. The possibility of a quantum leap in global scientific collaboration has been stymied by the China-US spat, which has reduced the prospects of shared funding and finance to fight the virus. The US, for instance, stopped funding of a critical coronavirus-related training program for Chinese and other scientists even before the current outbreak. National priorities have overridden collective action, which is entirely in accord with realist expectations (Baumgaertner and Rainey 2020).

The same malaise afflicts international institutions, which liberals see as fostering high levels of cooperation. The Group of 7 major economies (G7) failed to organize a summit meeting in March 2020, while a subsequent meeting of their foreign ministers came up with no more than an anodyne statement seeking to foster research cooperation and do "whatever is necessary" to counter the economic fallout of the crisis even as they disagreed on whether China was to blame for the onset of the crisis (Schult 2020). The G20 did not do much better. It did support debt relief for poor countries, but its announced $\$ 5$ trillion injection into the global economy was in fact no more than the sum of moneys already committed by its individual members for themselves (Chodor 2020). The institution at the center of the crisis, the WHO, has been acknowledged as critical to the information flow relating to the crisis. But the WHO has also been dogged by controversy for announcing the onset of the pandemic late (on 11 March, by which time it had already spread to 113 countries) and for apparently deferring to China in doing so (Basrur 2020). Such failings have brought much criticism and calls for its reform (South China Morning Post 2020).

Finally, democracy is said to be a binding factor, at least among developed economies. This is largely true with respect to the relationship between democracy and war. But the evidence is not persuasive in the present context. Developed democratic states in Europe and North America have engaged in recurring tugs of war over the sharing of counter-pandemic resources such as protective equipment and ventilators and have done relatively little to take collective action (Cohen and Musmar 2020). 
Overall, liberal theory does not have much to offer to explain the weak nature of international cooperation in the crisis.

\section{Ideational approaches}

The constructivist approach is an essentially ideational theory (or set of theories) that stresses the importance of belief structures, identities and roles, holding that, fundamentally, the ways in which actors behave in international politics are shaped by a consensus about reality and appropriate responses to it (Onuf 1989). From this standpoint, responses to the Covid-19 crisis are determined by deeply embedded beliefs about the priorities that states should adhere to in such a situation. The possibilities of cooperation, from a constructivist perspective, are not circumscribed by the anarchic condition in which states coexist (as realists would have it), but by our beliefs about what is feasible and what is not in such a condition (Pouliot 2011). The central dictum of the constructivist- "anarchy is what states make of it" (Wendt 1992) - thus sees the lack of collective action in the face of the pandemic not as an inevitable product of the material reality of the world as it actually is, but as arising from a realist thought structure. To wit, states fail to cooperate despite the urgency of the Covid-19 crisis because they are weighed down by the unquestioned notion that, even under the onslaught of a pandemic, self-help must come first, and the exercise of power must shape action. This worldview, for the constructivist, is an ideational construct that needs to be overridden if cooperation is to be achieved.

It is to the credit of constructivism that it widens the space for potential change by critiquing the realist perception of unalterable reality. However, while the concept of ideational structure is helpful in challenging established modes of thinking (and consequent habits of action) over time, it is not particularly helpful in offering insights into the short-to-medium-term responses of states to crises like the pandemic or to anticipating what, in fashioning states' responses, might actually be doable and what probably will not. On the contrary, since constructivist thinking views both cooperation and conflict in terms of thought structures, it explains very little as far as responses to the current crisis go. In short, constructivism is not a predictive theory and tends to be non-falsifiable and, more pragmatically, lacking in much utility other than urging new thinking. How to get from the present ideational structure to a more desirable one when a crisis breaks out remains a knotty problem.

Normative theory, which centers on moral judgment about what should be-as distinct from the materialist view of international politics as what is-is similarly problematic (Ramel 2011). Certainly, it offers useful space for the identification of responsibility when a crisis breaks out. The analyst may adopt two basic approaches that Robert Gregory labels "backward-mapping" and "forward-mapping" (Gregory 1998). The former looks at the origin and history of the policy process and how they might have created or contributed to the problem. In the present case, one would ask: who was responsible for the outbreak of the pandemic? A second question would be: was policymaker $\mathrm{X}$ warned about the problem and did he/she take action to avert it or mitigate its potential consequences? The latter approach considers the policy action taken at the time of the crisis. Did the policymaker act appropriately 
once the crisis had broken out? While both are normative questions, they also have strong practical implications. The attribution of responsibility relates to the consequences of the policymaker's actions and to whether the individual held responsible was fittingly sanctioned or punished for it, whether legally or politically. This has important implications. If the person or persons responsible is/are not in some way punished, he/she/they may tend to repeat this or similar errors and cause a recurrence of societal harm. Here, China would certainly be one center of analysis, as questions mount as to whether Beijing took the necessary steps to share information once the outbreak of the novel Coronavirus was first confirmed by Chinese medical doctors in late December (The Guardian 2020b). As mentioned above, the WHO too is open to the charge of prioritizing political expediency by not including Taiwan in its assessments and recommendations.

The problem, however, of explaining why states behave as they do remains. The attribution of responsibility for a crisis is normally only a post facto phenomenon and does little to inform the analyst as to why international cooperation as a pattern of behavior does or does not occur. Even more, the scope for anticipating future behavior remains uncertain at best. Like constructivism, normative theory is valuable in understanding critical aspects of international cooperation or the lack of it, but it misses some of the most important facets of international reality: it fails to explain why states tend to let competition override cooperation when individual and collective interests collide.

\section{Conclusion: realism redux}

Much post-Cold War academic thinking gave the appearance of a "transition" in the way intellectuals view global politics: a "decline" of realism and the rise of alternative approaches in apex-level scholarly research (Maliniak et al 2011). However, this analysis shows that alternative paradigms in IRT have much less grasp over the current crisis than realism. The continued dominance of the state and of individual national interests over collective interests in the absence of effective international authority is evident in global responses to the pandemic. Realism tells us that, because of the systemic trust deficit in international affairs, especially in times of crises, states will turn to self-help and zero-sum calculations rather than to cooperative collective action. It is evident that precisely such behavior dominates the global management of the Covid-19 crisis. To be sure, cooperation does occur, but only when it does not clash with national interest.

Going forward, a realist would expect further restrictions on international exchange in order to minimize the threat and at least a temporary but nonetheless significant scale-down of globalization, as it were. The economic effects of the crisis are likely to be severe and unpredictable, and likely to include recession, flight of capital, widespread impoverishment, fall in agricultural output, and increased deaths from other diseases such as malaria and HIV (Congressional Research Service 2020; Economist 2020; Shiller 2020). These will be subject to the same dynamics of cooperation and conflict as described here, in particular in the context of Sino-US competition. 
Rather worryingly, the Covid-19 crisis also points to what global action on other critical issues such as climate change, severe economic dislocation, or the apocalyptic consequences of nuclear war could look like in the future. They will in all probability not induce intense global cooperation to manage common challenges, but instead spur nationalism, zero-sum competition and the application of power to secure the objectives of individual nations.

On the positive side, realism also tells us that states try to imitate the successful activities of their peers. Governments may look jealously upon one another, but they will also adopt those measures used by others that are seen to be working. In that sense, we can place hope in the ability of Europeans and Americans to emulate successful measures taken by states like New Zealand, South Korea and Taiwan to contain the spread of Covid-19.

Clearly, while all branches of IRT have something to offer, realism is best equipped to explain and anticipate the ambit of international cooperation in a crisis of the magnitude of the Covid-19 pandemic. Discounting its value can only subtract from the potential of IR as a discipline to meet its social function.

\section{Compliance with ethical standards}

Conflicts of interest The authors declare no conflict of interest.

\section{References}

Apuzzo M, Kirkpatrick D (2020) Covid-19 changed how the world does science together. New York Times 1 April. https://www.nytimes.com/2020/04/01/world/europe/coronavirus-science-researchcooperation.html?campaign_id=2\&emc=edit_th_200402\&instance_id=17267\&nl=todayshead lines\&regi_id=30381051\&segment_id=23587\&user_id=fa090cc506ce13db9a05faea5d295a62. Accessed 1 April 2020

Basrur R (2020) Covid-19: transnational cooperation and the epistemic community, Takshashila Institution, April 2020. https://takshashila.org.in/covid-19-transnational-cooperation-and-the-epistemiccommunity/ Accessed 8 May 2020

Baumgaertner E, Rainey J (2020) Trump administration ended pandemic early-warning program to detect coronaviruses. Los Angeles Times, 2 April. https:/www.latimes.com/science/story/2020-04-02/ coronavirus-trump-pandemic-program-viruses-detection. Accessed 3 May 2020

Bradley J (2020) In scramble for supplies, rich countries push poor aside. MSN.com, 20 April. https ://www.msn.com/en-us/news/us/in-scramble-for-supplies-rich-countries-push-poor-aside/ar-BB12p fLy. Accessed 20 April 2020

Braw E (2020) The EU Is abandoning Italy in its hour of need. Foreign Policy 14 March. https://forei gnpolicy.com/2020/03/14/coronavirus-eu-abandoning-italy-china-aid/. Accessed 8 May 2020

Butler D (2012) SARS veterans tackle coronavirus. Nature 490:20

Chodor T (2020) Missing in action: The G20 in the Covid crisis. Interpreter 22 April. https://www.lowyi nstitute.org/the-interpreter/missing-action-g20-covid-crisis. Accessed 3 May 2020

Cohen E, Musmar F (2020) Coronavirus reveals the lack of unity at the EU and the UN. BESA Center Perspectives Paper 531, 15 April. https://besacenter.org/perspectives-papers/coronavirus-revealsthe-lack-of-unity-at-the-eu-and-the-un/. Accessed 3 May 2020

Cole H, Owen G (2020) Downing Street says China faces a 'reckoning' over their handling of coronavirus and risks becoming a 'pariah state' as Boris Johnson faces pressure to scrap the Huawei deal. Daily Mail 29 March. https://www.dailymail.co.uk/news/article-8163767/Downing-Street-saysChina-faces-reckoning-coronavirus.html. Accessed 3 May 2020

Congressional Research Service (2020) Global economic effects of Covid-19, 1 May. https://fas.org/sgp/ crs/row/R46270.pdf Accessed 31 August 2020 
Die Welt (2020) Diese Erfahrung wird Europa so schnell nicht vergessen. 15 March. https://www.welt.de/ wirtschaft/plus206563595/Trump-will-deutsche-Impfstoff-Firma-CureVac-Traumatische-Erfahrung. html. Accessed 8 May 2020

Doyle M, Recchia S (2011) Liberalism in international relations. In: Badie B, Berg-Schlosser D, Morlino L (eds) International encyclopaedia of political science. Sage, Newbury Park, CA, pp 1434-1439

Economist (2020) The Covid-19 pandemic will be over by the end of 2021, says Bill Gates. 18 August 2020. https://www.economist.com/international/2020/08/18/the-covid-19-pandemic-will-be-overby-the-end-of-2021-says-bill-gates Accessed 31 August 2020.

Financial Times (2020) Taiwan says WHO failed to act on coronavirus transmission warning. 20 March. https://www.ft.com/content/2a70a02a-644a-11ea-a6cd-df28cc3c6a68. Accessed on 2 April 2020

Gregory R (1998) Political responsibility for bureaucratic incompetence: tragedy at Cave Creek. Public Admin 76:519-538

Kliem F, Chong A (2020) Global health security: COVID-19 and its impacts-China-Taiwan mask diplomacy: wooing Southeast Asia? RSIS Commentaries. https://www.rsis.edu.sg/rsis-publication/cms/ global-health-security-covid-19-and-its-impacts-china-taiwan-mask-diplomacy-wooing-southeastasia/\#.XrUnPy2Q3UI. Accessed 8 May 2020

MacCharles T, Ballingall A (2020). Stop exporting N95 masks to Canada, Trump administration tells U.S. manufacturer, Star 3 April. https://www.thestar.com/politics/federal/2020/04/03/stop-expor ting-n95-masks-to-canada-trump-administration-tells-us-manufacturer.html. Accessed 8 May 2020

Maliniak D, Oakes A, Peterson S, Tierney M (2011) International relations in the academy. Int Stud Quart 55:437-464

Morgenthau H (1985) Politics among nations: the struggle for power and peace, 6th edn. Knopf, New York

Nye J (1988) Neorealism and neoliberalism. World Politics 40:235-251

Onuf N (1989) World of our making: rules and rule in social theory and international relations. University of South Carolina Press, Columbia

Pamuk H and Shalal A (2020) Trump administration pushing to rip global supply chains from China: officials. Reuters, 4 May https://www.reuters.com/article/us-health-coronavirus-usa-china/trump-admin istration-pushing-to-rip-global-supply-chains-from-china-officials-idUSKBN22G0BZ. Accessed 8 May 2020

Pouliot V (2011) Constructivism in International Relations. In: Badie B, Berg-Schlosser D, Morlino L (eds) International encyclopaedia of political science. Sage, Newbury Park, CA, pp 426-431

Ramel F (2011) Normative theory in International Relations. In: Badie B, Berg-Schlosser D, Morlino L (eds) International encyclopaedia of political science. Sage, Newbury Park, CA, pp 1727-1737

Reuters (2020) Germany bans export of medical protection gear due to coronavirus. 4 March. https:// www.reuters.com/article/health-coronavirus-germany-exports/germany-bans-export-of-medicalprotection-gear-due-to-coronavirus-idUSL8N2AX3D9. Accessed 8 May 2020.

Ripsman N, Taliaferro J, Lobell S (2016) Neoclassical realist theory of international politics. Oxford University Press, New York

Rudd K (2020) The coming post-COVID anarchy. Foreign Affairs, 6 May https://www.foreignaffairs. com/articles/united-states/2020-05-06/coming-post-covid-anarchy. Accessed 8 May 2020

Schult C (2020) Streit über 'Wuhan-Virus.' Der Spiegel 24 March. https://www.spiegel.de/politik/ausla nd/streit-um-wuhan-virus-a-6bb570bb-9f2b-4cd1-a895-fdeabf53f6b4. Accessed 3 May 2020

Shi J and Wu W (2020) Coronavirus infects China-US relations as blame game over pandemic intensifies. South China Morning Post 27 April. https://www.scmp.com/news/china/diplomacy/article/3081601/ coronavirus-infects-china-us-relations-blame-game-over. Accessed 8 May 2020

Shiller R (2020) Why we can't foresee the pandemic's long-term effects. New York Times 31 May, updated 4 August. https://www.nytimes.com/2020/05/29/business/coronavirus-economic-forecastshiller.html. Accessed 31 August 2020.

South China Morning Post (2020) Coronavirus: G7 seeking WHO review and reform. White House says, 17 April. https://www.scmp.com/news/world/united-states-canada/article/3080303/coronavirus-g7seeking-who-review-and-reform-white. Accessed 3 May 2020

The Guardian (2020a) Just when Italy really needed some unity, the EU failed it - and continues to do so. 19 April. https://www.theguardian.com/world/2020/apr/19/european-union-italy-unity-failure-debtgermany-netherlands. Accessed 19 April 2020

The Guardian (2020b) China bristles at Australia's call for investigation into coronavirus origin, 29 April. https://www.theguardian.com/world/2020/apr/29/australia-defends-plan-to-investigate-china-overcovid-19-outbreak-as-row-deepens. Accessed 8 May 2020 
Tribune (2020) US in talks with India, other 'friends' to restructure global supply chains: Pompeo. 30 April. https://www.tribuneindia.com/news/nation/us-in-talks-with-india-other-friends-to-restructur e-global-supply-chains-pompeo-78487. Accessed 30 April 2020

Waltz K (1979) Theory of international politics. McGraw Hill, New York

Wendt A (1992) Anarchy is what states make of it: the social construction of power politics. Int Organ 46:391-425

Zyoud S (2016) Global research trends of Middle East respiratory syndrome coronavirus: a bibliometric analysis. BMC Infect Dis 16:255. https://doi.org/10.1186/s12879-016-1600-5 